\title{
Prevalence and factors associated with anthropometric failure, vitamin A and iron deficiency among adolescents in a Nigerian urban community.
}

\author{
Rufina NB Ayogu, Ngozi M Nnam, Onyinye Ibemesi, Franca Okechukwu
}

University of Nigeria, Nsukka.

\begin{abstract}
Background: Under nutrition is a problem of severe magnitude in low income countries like Nigeria. Adolescent school children might also be vulnerable. The dearth of data hinders planning of school health and nutrition programmes for school children.

Objective: To determine the prevalence of stunting, thinness; vitamin A and iron deficiencies among adolescent students in Nsukka urban, Nigeria and to determine factors that are associated with these nutritional problems.

Methods: A total of 400 participants were randomly selected from 717 students aged $12-18$ years in 3 randomly selected secondary schools. Questionnaires, anthropometric measurements, and blood analyses were the data collection methods employed. Results: The prevalence of stunting was $33.3 \%$ and thinness $31.0 \%$. Neither overweight nor obesity was observed. While $64.0 \%$ were anaemic; $44.0 \%$ had vitamin A deficiency (VAD). A total of $48.0 \%$ had both anaemia and stunting, $42 \%$ had VAD + thinness; while $40 \%$ had anaemia + VAD. Household income was a predictor of vitamin A status. Children from medium/ high income households had higher odds of having VAD than those from low income households $(\mathrm{AOR}=0.14 ; 95 \% \mathrm{CI}=0.031$, 0.607; $\mathrm{P}=0.009$ ). Household income ( $\mathrm{AOR}=0.12 ; 95 \% \mathrm{CI}=0.021,0.671 ; \mathrm{P}=0.016$ ), and age (AOR=0.09; $95 \% \mathrm{CI}=0.014,0.587$; $\mathrm{P}=0.012$ ) were independent determinants of height-for-age status.
\end{abstract}

Conclusion: Among urban adolescent students in Nigeria, stunting, thinness, anaemia and VAD were problems of public health significance. Age and household monthly income played major roles.

Keywords: School adolescents, anaemia, stunting, thinness, vitamin A deficiency.

DOI: http://dx.doi.org/10.4314/ahs.v16i2.7

Cite as: Ayogu RNB, Nnam NM, Ibemesi O, Okechukwn F. Prevalence and factors associated with anthropometric failure, vitamin $A$ and iron deficiency among adolescents in a Nigerian urban community. Afri Health Sci 2016;16(2): 389-398. http://dx.doi. org/10.4314/abs.v16i2.7

\section{Introduction}

Adolescence is a period marked by rapid growth ${ }^{1}$. Increased nutrient requirements in adolescence is a vital pre-requisite to ensuring that they gain about $50 \%$ of their adult weight and skeletal mass as well as $20 \%$ of their adult height as postulated by Brasel ${ }^{2}$. Food insecurity in most households in low income countries makes it difficult to meet the high nutrient requirements for this age group. This invariably results to malnutrition. Muller $^{3}$ observed that malnutrition particularly under nutrition is still highly prevalent in low income countries. Though

\section{Corresponding author: \\ Rufina NB Ayogu, University of Nigeria, Nsukka \\ Phone: +2348063293183 \\ Email: rufina.ayogu@unn.edu.ng; \\ lomearnb@yahoo.com}

malnutrition is prevalent among the under fives, children above this age and particularly adolescents are not spared. Adolescents remain a largely neglected, difficult-to-measure and hard-to-reach population ${ }^{4}$. They consequently face numerous serious nutritional challenges which affect their physical growth, cognitive development and health. Under five children are generally prioritized for nutrition assessment and interventions because under nutrition is more widespread than among older children. School children above five years, especially adolescents, have been shown to be equally affected by anaemia ${ }^{5}$, vitamin A deficiency ${ }^{6}$ and parasitic infections ${ }^{5,7}$. Rural areas have also been given priority over urban areas implying that malnutrition and other health problems are more prevalent in these areas than urban areas. School children in urban areas may also be prone to malnutrition and other health problems.

The dearth of data on the nutritional status of adolescents particularly iron status ${ }^{5}$ makes it difficult to define 
appropriate intervention strategies for them. The Nigeria Food consumption and nutrition survey ${ }^{8}$ provided $\mathrm{Na}$ tional data on the nutritional status of the under fives and clearly neglected children above five years, school children inclusive.

It is necessary to assess the nutritional status of adolescent school children since they constitute about $60 \%$ of the Nigerian society ${ }^{9}$. This would provide data that will create awareness on adolescent nutritional status and facilitate planning of interventions to curb nutritional inadequacies among this growing population whether in the rural or urban areas.

\section{Methods}

Study site: The study was carried out in Nsukka urban in which the Nsukka campus of the University of Nigeria is situated.

Study design: This was a descriptive cross-sectional.

Participants: Participants were adolescent school children aged 12-18 years in secondary schools within Nsukka urban of Enugu state, Nigeria.

\section{Sample size and sampling procedure:}

The sample size was determined by the formula:

$\mathrm{N}=\frac{\mathrm{t}^{2} \times \mathrm{p}(1-\mathrm{p})}{\mathrm{m}^{2}}$

Where $\mathrm{N}=$ required sample size

$\mathrm{t}=$ confidence level at $95 \%$ (standard value of 1.96 )

$\mathrm{p}=$ estimated prevalence of malnutrition in the project area

$\mathrm{m}=$ margin of error at $5 \%$ (standard value of 0.05$)$.

We estimated the prevalence of stunting (indicator of chronic malnutrition) among adolescent school children in Nsukka urban to be $14 \%$. The value got was multiplied by 2 , the design effect (DEFF) generally accepted for nutrition surveys and increased by $5 \%$ to account for nonresponse or recording error. The total (389) was rounded off to 400 .

Three secondary schools in Nsukka urban were selected by simple random sampling technique (using balloting without replacement). These schools were Model Secondary School (MSS), St. Cyprian's Girls' Secondary School (SCGSS) and Urban Boys' Secondary School (UBSS). A total of 717 school children within 12-18 years were in these 3 schools: MSS had 275, SCGSS had 252 and UBSS had 190. Proportionate stratified random sampling technique was used to determine the sample size per school: MSS had 153, SCGSS had 141 and UBSS had 106. Age and sex of the students, classes and schools formed the strata. The sample per school was selected using simple random sampling technique. A sub-sample of fifty students was selected for biochemical analyses. The subsample for each school was also determined by simple proportion and the participants selected by simple random sampling technique. The sample was stratified into 2 according to $\mathrm{UNICEF}^{10}$ classification of adolescents. The first group was made up of early adolescents aged $12-14$ years. Those in their late adolescence (15-18 years) formed the second group.

Exclusion criteria: Any adolescent whose age could not be ascertained was excluded from the study.

Instrumentation: The instruments used for data collection were validated and pre-tested questionnaire, anthropometric measurements of weight and height, and blood analyses of iron and vitamin A.

Procedure: The validated questionnaire was used to obtain data on the socio-economic background of the children and their consumption pattern of iron and vitamin A rich foods. Weight and height were the anthropometric measurements taken. They were weighed with Harson's bathroom Salter scale (120 Kg capacity, CAMRY model H89, China). Each child was made to stand erect (head upright and hands hanging by the sides) on the centre of the horizontal platform without touching anything. Very minimal clothing was allowed. Bladder was emptied prior to weighing. Reading was taken to the nearest $0.1 \mathrm{~kg}$.

Height was taken with microtoise height measure (CMS Weights Ltd, London). With their feet parallel, their heels, buttocks, shoulders and back of the head made to touch the upright part of the metre rule. The head was held comfortably erect in the same horizontal plane as the external auditory meatus. The arms hung at the sides in a natural manner. The reading was taken to the nearest $0.1 \mathrm{~cm}$ by lowering the head piece until it came in direct contact with the top of the child's head.

These measurements were taken twice and the mean used in statistical analysis. A third measurement was taken if 
the difference between the two readings was greater than $0.2 \mathrm{~kg}$ for weight or $0.5 \mathrm{~cm}$ for height. The mean of the 2 closest reading was used in statistical analysis ${ }^{11}$.

Body mass index (BMI) was calculated from the weight and height measurements. Values of height and BMI were related to age and compared with $\mathrm{WHO}^{12}$ standard for height-for-age and BMI-for-age z-scores. Children were classified as stunted and thin if z-scores of heightfor-age and BMI-for-age were $\leq-2 \mathrm{SD}$ (moderate and severe)below the WHO median. Mild (-1), moderate (-2) and severe $(-3)$ were specific terms used to describe the degree of stunting and thinness. Overweight was taken as +2 and +3 for obesity.

Biochemical analyses: Five millilitres of venous blood was collected by a laboratory scientist from each of the 50 school children that made up the sub-sample using standard sterile procedures. Two millilitres were collected into sample bottles with ethylene diamine tetra acetic acid (EDTA). Haemoglobin and packed cell volume were determined from this sample. Cyanmethaemoglobin method was used in the determination of haemoglobin $(\mathrm{Hb})$ values of the samples. Packed cell volume (PCV) was determined by the micro-haematocrit method. Anaemia was taken as values of haemoglobin and packed cell volume lower than $12 \mathrm{~g} / \mathrm{dl}$ and $36 \%$, respectively ${ }^{13}$.

Three millilitres of venous blood were put into another screw capped glass vials without anticoagulant. The glass vials were labelled appropriately and put into a cooler lined with frozen ice packs. The samples in bottles without anti coagulant were centrifuged at $3000 \mathrm{rpm}$ for 10 minutes. Serum retinol was analysed from this sample using the trifluoroacetic acid (TFA) method ${ }^{14}$. Colorimetric method using TFA was chosen on the basis of availability and cost. Values were matched with standards and correction was done using this formula:

$2 \mathrm{X} \mathrm{A}_{450} \mathrm{X} \mathrm{FC}_{450}$

$\mathrm{FC}_{620}$
The results were classified according to Federal Ministry of Health ${ }^{15}$ standard.

Ethical consideration: The study was approved by the Health Research Ethical Committee of the University of Nigeria Teaching Hospital, Ituku Ozalla, Enugu in Enugu State, Nigeria (NHRED 05/01/2008B). Informed consent was obtained by distributing the forms to the selected students for their parents to indicate their willingness to allow their children to participate in the study. Oral consent was also obtained from the students.

\section{Statistical analysis}

Data was analyzed using descriptive and inferential statistics of SPSS (version 16). Means, frequencies and percentages were computed by descriptive statistics to indicate values for anthropometric measurements, vitamin A and haemoglobin; general characteristics of the children and prevalence of nutritional problems. Binary and multivariate logistic analysis was carried out to test for the presence and strength of associations between outcomes and explanatory variables. Adjustments for simultaneous effects of multiple factors and control of the effects of confounders on the outcome variables were achieved through multivariate logistic regression. Probability level of $<0.05$ was considered significant.

\section{Results}

Adolescent school children (400) were involved in this study to determine the prevalence of stunting, thinness; vitamin $A$ and iron deficiencies in Nsukka urban, Nigeria and also determine factors associated with these nutritional problems.

The mean weight $(48.2 \mathrm{~kg})$ and height $(151.9 \mathrm{~cm})$ of the $12-14$ year olds were significantly $(p<0.001)$ different from the mean weight $(56.3 \mathrm{~kg})$ and height $(160.9 \mathrm{~cm})$ of the 15-18 years but their BMI $\left(20.9\right.$ and $\left.22.4 \mathrm{~kg} / \mathrm{m}^{2}\right)$ were similar $(\mathrm{P}>0.05)$. There was no significant $(\mathrm{P}>0.05)$ difference in their haemoglobin (11.5 and $11.5 \mathrm{~g} / \mathrm{dl}), \mathrm{PCV}$ (34.6 and $35.4 \%$ ) and serum retinol (28.5 and $30.9 \mu \mathrm{g} / \mathrm{dl})$ values (Table 1$)$. 


\begin{tabular}{|c|c|c|c|}
\hline \multicolumn{2}{|l|}{ Variables } & Frequency & Percentage \\
\hline \multicolumn{4}{|l|}{ Age } \\
\hline \multicolumn{2}{|l|}{$12-14$ years } & 169 & 42.2 \\
\hline \multicolumn{2}{|l|}{$15-18$ years } & 231 & 57.8 \\
\hline \multicolumn{2}{|l|}{ Total } & 400 & 100.0 \\
\hline \multicolumn{4}{|l|}{ Sex } \\
\hline \multicolumn{2}{|l|}{ Male } & 225 & 56.3 \\
\hline \multicolumn{2}{|l|}{ Female } & 175 & 43.7 \\
\hline \multicolumn{2}{|l|}{ Total } & 400 & 100.0 \\
\hline \multicolumn{4}{|l|}{ Household monthly income } \\
\hline \multicolumn{2}{|l|}{20000 and below $(\$ 120.96)$} & 4 & 0.9 \\
\hline \multicolumn{2}{|l|}{$21000-40000(\$ 127.00-247.91)$} & 60 & 14.9 \\
\hline \multicolumn{2}{|l|}{$41000-60000(\$ 247.96-362.87)$} & 58 & 14.4 \\
\hline \multicolumn{2}{|l|}{$61000-80000(\$ 368.92-483.82)$} & 138 & 34.5 \\
\hline \multicolumn{2}{|c|}{$81000-100000(\$ 489.87-604.78)$} & 78 & 19.5 \\
\hline \multicolumn{2}{|c|}{101000 and above $(\geq \$ 610.78)$} & 62 & 15.8 \\
\hline \multicolumn{2}{|l|}{ Total } & 400 & 100.0 \\
\hline \multicolumn{4}{|l|}{ Household size (persons) } \\
\hline \multicolumn{2}{|l|}{$1-3$} & 104 & 26.0 \\
\hline \multicolumn{2}{|l|}{$4-7$} & 227 & 56.8 \\
\hline \multicolumn{2}{|l|}{8 and above } & 69 & 17.2 \\
\hline \multicolumn{2}{|l|}{ Total } & 400 & 100.0 \\
\hline \multicolumn{4}{|l|}{ Occupation of the father } \\
\hline \multicolumn{2}{|l|}{ Trading } & 88 & 22.1 \\
\hline \multicolumn{2}{|l|}{ Farming } & 82 & 20.4 \\
\hline \multicolumn{2}{|l|}{ Artisan } & 94 & 23.5 \\
\hline Civil servant & & 136 & 34.0 \\
\hline Total & & 400 & 100.0 \\
\hline Occupation of the mother & & & \\
\hline Trading & & 132 & 33.0 \\
\hline Farming & & 86 & 21.4 \\
\hline Artisan & & 76 & 19.1 \\
\hline Civil servant & & 106 & 26.5 \\
\hline Total & & 400 & 100.0 \\
\hline & 12 - 14years & 15 - 18 years & T (P values) \\
\hline Mean weight (kg) & 48.2 & 56.3 & $5.154(0.000)$ \\
\hline Mean height $(\mathrm{cm})$ & 151.9 & 160.9 & $6.244(0.000)$ \\
\hline Mean body mass index $\left(\mathrm{kg} / \mathrm{m}^{2}\right)$ & 20.9 & 22.4 & $1.588(0.054)$ \\
\hline Mean haemoglobin $(\mathrm{g} / \mathrm{dl})$ & 11.5 & 11.5 & $0.426(0.746)$ \\
\hline Mean packed cell volume (\%) & 34.6 & 35.4 & $0.599(0.636)$ \\
\hline Mean serum retinol $(\mu \mathrm{g} / \mathrm{dl})$ & 28.5 & 30.9 & $1.589(0.058)$ \\
\hline
\end{tabular}


Table 2: Weekly consumption pattern of iron and vitamin A rich foods

\begin{tabular}{|c|c|c|c|c|c|}
\hline Foods & $\begin{array}{l}\text { Weekly } \\
\text { N (\%) }\end{array}$ & $\begin{array}{c}2 \text { times } \\
\text { N }(\%)\end{array}$ & $\begin{array}{c}3 \text { times } \\
\text { N (\%) }\end{array}$ & $\begin{array}{c}>3 \text { times } \\
\mathbf{N}(\%)\end{array}$ & $\begin{array}{l}\text { Total } \\
\text { N (\%) }\end{array}$ \\
\hline Legumes & $59(14.8)$ & $96(24.0)$ & $216(54.0)$ & $29(7.2)$ & $400(100.0)$ \\
\hline d vegetables & ) & 106 & 143 & 39 & \\
\hline and nuts & $7(3-x)+x)$ & 68 & $91(22.8)$ & $104(26.0)$ & $00.0)$ \\
\hline Meat a & $143(35.8)$ & 157( & $40(10.0)$ & $60(15.0)$ & $400(100.0)$ \\
\hline Margarine/butter & $142(35.5)$ & $15(3.8)$ & $193(48.2)$ & $50(12.5)$ & $400(100.0)$ \\
\hline Red $p$ & $4(1.0)$ & $10(2.5)$ & $116(29.0)$ & $270(67.5)$ & $400(100.0)$ \\
\hline *Vegetable oil & $258(64.5)$ & $85(21.5)$ & $37(9.2)$ & $20(5.0)$ & $400(100.0)$ \\
\hline
\end{tabular}

Stunting affected $33.3 \%$ while $31.0 \%$ were affected by thinness (Table 3).

Table 3: Anthropometric indices, iron and vitamin A status of the school children

\begin{tabular}{|c|c|c|c|}
\hline Variables & $\begin{array}{l}12-14 \text { years } \\
\text { N }(\%)\end{array}$ & $\begin{array}{c}15-18 \text { years } \\
\mathrm{N}(\%)\end{array}$ & $\begin{array}{l}\text { Total } \\
\text { N (\%) }\end{array}$ \\
\hline \multicolumn{4}{|c|}{ Body Mass Index-for-age $(\mathrm{N}=400)$} \\
\hline Mild thinness (-1SD) & $76(45.0)$ & $52(22.5)$ & $128(32.0)$ \\
\hline Moderate thinness (-2SD) & $25(14.8)$ & $73(31.6)$ & $98(24.5)$ \\
\hline Severe thinness $(-3 \mathrm{SD})$ & $12(7.1)$ & $14(6.1)$ & $26(6.5)$ \\
\hline Normal & $56(33.1)$ & $92(39.8)$ & $148(37.0)$ \\
\hline Overweight $(+2 \mathrm{SD})$ & $0(0.0)$ & $0(0.0)$ & $0(0.0)$ \\
\hline Obesity (+3SD) & $0(0.0)$ & $0(0.0)$ & $0(0.0)$ \\
\hline \multirow{2}{*}{\multicolumn{4}{|c|}{ Height-for-age $(\mathrm{N}=400)$}} \\
\hline & & & \\
\hline Mild stunting (-1SD) & $25(14.8)$ & $79(34.2)$ & $104(26.0)$ \\
\hline Moderate stunting (-2SD) & $64(37.9)$ & $41(17.8)$ & $105(26.3)$ \\
\hline Severe stunting $(-3 \mathrm{SD})$ & $21(12.4)$ & $7(3.0)$ & $28(7.0)$ \\
\hline Normal & 59 (34.9) & $104(45.0)$ & $163(40.7)$ \\
\hline Total & $169(100.0)$ & $231(100.0)$ & $400(100.0)$ \\
\hline \multicolumn{4}{|l|}{ Haemoglobin (g/dl) $(\mathbf{N}=\mathbf{5 0})$} \\
\hline Mild anaemia $(10.0-11.9)$ & $3(23.1)$ & $14(37.8)$ & $17(34.0)$ \\
\hline Moderate anaemia $(7.0-9.9)$ & $4(30.8)$ & $8(21.6)$ & $12(24.0)$ \\
\hline Severe anaemia $(<7.0)$ & $3(23.1)$ & $0(0.0)$ & $3(6.0)$ \\
\hline Normal $(\geq 12.0)$ & $3(23.0)$ & $15(40.6)$ & $18(36.0)$ \\
\hline \multirow{2}{*}{\multicolumn{4}{|c|}{ Packed cell volume $(\%)(\mathrm{N}=50)$}} \\
\hline & & & \\
\hline Low $(<36)$ & $9(69.2)$ & $12(32.4)$ & $21(42.0)$ \\
\hline Normal ( $\geq 36)$ & $4(30.8)$ & $25(67.6)$ & $29(58.0)$ \\
\hline Total & $13(100.0)$ & 37 (100.0) & $50(100.0)$ \\
\hline \multicolumn{4}{|l|}{ Vitamin $A(\mu \mathrm{g} / \mathrm{dl})(\mathrm{N}=\mathbf{5 0})$} \\
\hline Deficiency $(\leq 20.0)$ & $6(46.2)$ & $16(43.2)$ & $22(44.0)$ \\
\hline $\operatorname{Normal}(>20.0)$ & $7(53.8)$ & $21(56.8)$ & $28(56.0)$ \\
\hline Total & $13(100.0)$ & $37(100.0)$ & $50(100.0)$ \\
\hline
\end{tabular}


deficiency (VAD). Only 11.0\% had no form of malnutrition (Table 4).

Table 4: Prevalence of compound malnutrition among the school children

\begin{tabular}{|c|c|c|c|c|}
\hline Variables & $\begin{array}{c}12-14 \text { years } \\
\mathrm{N}(\%) \\
\end{array}$ & $\begin{array}{l}15-18 \text { years } \\
\mathrm{N}(\%)\end{array}$ & $\begin{array}{l}\text { Total } \\
\mathbf{N}(\%) \\
\end{array}$ & $\chi^{2}$ (P value) \\
\hline$* *$ None & $26(15.4)$ & $18(7.8)$ & $44(11.0)$ & $15.668(0.012)$ \\
\hline$* *$ Stunting only & $85(50.3)$ & $48(20.8)$ & $133(33.3)$ & $12.312(0.022)$ \\
\hline **Thinness only & 37 (21.9) & $87(37.7)$ & $124(31.0)$ & $10.566(0.035)$ \\
\hline *Anaemia + stunting & $8(61.5)$ & $16(43.2)$ & $24(48.0)$ & $11.416(0.032)$ \\
\hline$*$ Anaemia + thinness & $6(46.2)$ & $12(32.4)$ & $18(36.0)$ & $10.212(0.039)$ \\
\hline$* \mathrm{VAD}+$ stunting & $4(30.8)$ & $10(27.0)$ & $14(28.0)$ & $6.925(0.140)$ \\
\hline *VAD + thinness & $5(38.5)$ & $16(43.2)$ & $21(42.0)$ & $9.175(0.052)$ \\
\hline$* *$ Stunting + thinness & $20(11.8)$ & $18(7.8)$ & $38(9.5)$ & $7.455(0.114)$ \\
\hline$*$ Anaemia + VAD & $6(46.1)$ & $14(37.8)$ & $20(40.0)$ & $9.020(0.068)$ \\
\hline $\begin{array}{l}* \text { Anaemia }+ \text { stunting }+ \\
\text { thinness }\end{array}$ & $4(30.8)$ & $8(21.6)$ & $12(24.0)$ & $1.038(0.595)$ \\
\hline $\begin{array}{l}* \mathrm{VAD}+\text { stunting } \\
\text { thinness }\end{array}$ & $2(15.4)$ & $6(16.2)$ & $8(16.0)$ & $3.377(0.497)$ \\
\hline $\begin{array}{l}* \text { Anaemia }+ \text { VAD }+ \\
\text { stunting }+ \text { thinness }\end{array}$ & $1(7.7)$ & $3(8.1)$ & $4(8.0)$ & $2.083(0.837)$ \\
\hline
\end{tabular}

Multivariate analysis showed that effect of household income on height-for-age $(\mathrm{AOR}=0.12 ; 95 \% \mathrm{CI}=0.021$, $0.671 ; \mathrm{P}=0.016)$ and serum retinol $(\mathrm{AOR}=0.14 ; 95 \%$ $\mathrm{CI}=0.031,0.607 ; \mathrm{P}=0.009)$ status remained high after ad- justment for other variables (Table 5).

Low household income was associated with anaemia but this did not attain statistically significant proportion $(\mathrm{AOR}=0.84 ; 95 \% \mathrm{CI}=0.204,3.478 ; \mathrm{P}=0.813)$. 


\begin{tabular}{|c|c|c|c|c|c|c|}
\hline \multicolumn{2}{|c|}{ Independent variables } & \multicolumn{2}{|c|}{ Dependent variables } & COR $(95 \% \mathrm{CI})$ & AOR $(95 \%$ CI) & $\begin{array}{c}\mathbf{P} \\
\text { value } \\
\end{array}$ \\
\hline & & \multicolumn{2}{|c|}{ Haemoglobin } & & & \\
\hline & & Normal & Anaemic & & & \\
\hline \multirow[t]{2}{*}{ Age } & $12-14$ & 3 & 10 & 1.00 & & \\
\hline & $15-18$ & 15 & 22 & $0.44(0.10,1.87)$ & $0.76(0.13,4.43)$ & 0.762 \\
\hline \multirow[t]{2}{*}{$\begin{array}{l}\text { Household } \\
\text { size }\end{array}$} & $1-7$ & 14 & 21 & 1.00 & & \\
\hline & $>7$ & 4 & 11 & $1.83(0.49,6.93)$ & $1.90(0.46,7.79)$ & 0.375 \\
\hline \multirow[t]{2}{*}{$\begin{array}{l}\text { Household } \\
\text { income }\end{array}$} & Low & 7 & 17 & 1.00 & & \\
\hline & Medium/High & 11 & 15 & $0.56(0.17,1.82)$ & $0.84(0.20,3.48)$ & 0.813 \\
\hline \multirow[t]{2}{*}{ VAD } & Absent & 11 & 17 & 1.00 & & \\
\hline & Present & 7 & 15 & $1.39(0.43,4.49)$ & $1.37(0.36,5.15)$ & 0.641 \\
\hline \multirow[t]{2}{*}{ Stunting } & Absent & 13 & 18 & 1.00 & & \\
\hline & Present & 5 & 14 & $2.02(0.58,7.03)$ & $1.69(0.36,7.89)$ & 0.504 \\
\hline \multirow[t]{4}{*}{ Thinness } & Absent & 15 & 24 & 1.00 & & \\
\hline & Present & 3 & 8 & $1.67(0.38,7.29)$ & $1.73(0.33,9.20)$ & 0.520 \\
\hline & & \multicolumn{2}{|c|}{ serum retinol } & & & \\
\hline & & Normal & Deficient & & & \\
\hline \multirow[t]{2}{*}{$\begin{array}{l}\text { Household } \\
\text { size }\end{array}$} & $1-7$ & 20 & 15 & 1.00 & & \\
\hline & $>7$ & 8 & 7 & $1.17(0.35,3.93)$ & $0.80(0.21,3.12)$ & 0.751 \\
\hline \multirow[t]{2}{*}{$\begin{array}{l}\text { Household } \\
\text { income }\end{array}$} & Low & 9 & 15 & 1.00 & & \\
\hline & Medium/High & 19 & 7 & $0.22(0.07,0.73)$ & $0.14(0.03,0.61)$ & 0.009 \\
\hline \multirow[t]{2}{*}{ Anaemia } & Absent & 11 & 7 & 1.00 & & \\
\hline & Present & 17 & 15 & $1.39(0.43,4.49)$ & $1.34(0.36,4.99)$ & 0.667 \\
\hline \multirow[t]{2}{*}{ Stunting } & Absent & 17 & 14 & 1.00 & & \\
\hline & Present & 11 & 8 & $0.88(0.28,2.80)$ & $0.31(0.06,1.61)$ & 0.162 \\
\hline \multirow[t]{4}{*}{ Thinness } & Absent & 21 & 18 & 1.00 & & \\
\hline & Present & 7 & 4 & $0.67(0.17,2.65)$ & $0.62(0.12,3.21)$ & 0.570 \\
\hline & & Height-fo & age & & & \\
\hline & & Normal & Low & & & \\
\hline \multirow[t]{2}{*}{ Age } & $12-14$ & 3 & 10 & 1.00 & & \\
\hline & $15-18$ & 28 & 9 & $0.10(0.02,0.43)$ & $0.09(0.01,0.59)$ & 0.012 \\
\hline \multirow[t]{2}{*}{$\begin{array}{l}\text { Household } \\
\text { size }\end{array}$} & $1-7$ & 22 & 13 & 1.00 & & \\
\hline & $>7$ & 9 & 6 & $1.13(0.33,3.90)$ & $0.56(0.11,2.89)$ & 0.558 \\
\hline \multirow[t]{2}{*}{ VAD } & Absent & 17 & 11 & 1.00 & & \\
\hline & Present & 14 & 8 & $0.88(0.28,2.80)$ & $0.31(0.06,1.69)$ & 0.177 \\
\hline \multirow[t]{2}{*}{ Anaemia } & Absent & 13 & 5 & 1.00 & & \\
\hline & Present & 18 & 14 & $2.00(0.58,7.03)$ & $1.63(0.33,8.16)$ & 0.554 \\
\hline \multirow[t]{2}{*}{ Thinness } & Absent & 25 & 14 & 1.00 & & \\
\hline & Present & 6 & 5 & $1.49(0.38,5.77)$ & $0.55(0.08,3.99)$ & 0.551 \\
\hline
\end{tabular}

\section{Discussion}

Most local dishes consumed in Nsukka are legume based. The low legume consumption of $\leq 3$ times a week observed in this study is worrisome. It implies a shift from indigenous dishes to processed foods. Changes in life style including food habits are often more obvious among urban adolescents ${ }^{11}$. This could be one of the reasons for the high prevalence of malnutrition observed among the school children in Nsukka urban of Enugu State, Nigeria.

Micronutrient deficiencies (iron deficiency anaemia and vitamin A deficiency) were problems of severe public health significance among these school children.More than half $(64.0 \%)$ had anaemia and $44.0 \%$ of them had vitamin A deficiency (VAD). These high rates were similar to the observations from previous studies ${ }^{5,6,11}$. As- sefa et al. ${ }^{16}$ also reported anaemia prevalence of $30.1 \%$ among 12-14 year old school children in Ethiopia. VAD $(42.22 \%)$ has also been reported among school going adolescents ${ }^{17}$. Of particular worry was the percentage affected by a combination of anaemia + stunting, VAD + thinness and VAD + anaemia. Up to $8.0 \%$ had a combination of four forms of malnutrition. This may be due to low consumption of iron and vitamin A rich foods as well as the developmental stage of the school children which is characterised by rapid growth and high nutrient requirements. Low consumption of animal protein which is in line with the findings of Ngwu et al. ${ }^{18}$ was attributed to cost, cultural beliefs and ignorance.

That more females were affected by anaemia was expected. The onset of menstruation imposes additional iron 
needs on females and with low consumption of iron rich foods; this may be difficult to meet. The high prevalence of anaemia may not be due to low consumption of iron rich foods alone. VAD has been associated with anaemia $^{19}$. Besides, the Federal Ministry of Health ${ }^{15}$ identified inadequate dietary intake, parasitic infections and menstrual losses as major causes of iron deficiency anaemia in Nigeria. Seasonality of vitamin A rich foods also adds to the burden of $\mathrm{VAD}^{20}$.

The study also showed that stunting and thinness were problems affecting school going children. The prevalence of stunting reported in this study was lower than the observations of some researchers ${ }^{5,21}$ but higher than the report of others ${ }^{22,23}$. More males were affected and this is in line with the report of Okeke et $\mathrm{al}^{24}$. The prevalence of stunting reflects long standing nutritional inadequacies as well as chronic/recurrent infections. Stunting in this study was a function of age and household income. Anaemia and VAD among other factors could also have caused the prevalence of stunting and thinness reported in this study. Anaemia and vitamin A deficiency have been associated with poor growth ${ }^{20,25}$ through a well defined physiological pathway. The children studied were at a period marked by rapid growth and development and increased nutrient requirements. Inability to provide the needed nutrients in the right quantities would result to malnutrition.

The higher prevalence of stunting $(\mathrm{P}<0.05)$ among the 12-14 years was a surprise and contradicts previous studies $^{11,26}$ in which stunting affected older school children more than younger ones. The reason for this could not be ascertained but the researchers attributed it to the fact that this age group may have had severe nutritional deprivation when they were younger (in the first few years of life) than the older children. Martorell et al. ${ }^{27}$ reported that catch-up growth could occur with improvements in living conditions more effectively in very young children than older children. However, if the children remained in similar impoverished conditions, there was little or no possibility that catch-up growth would occur. Therefore, stunting in school children and adolescents may be less reversible and consequently could lead to short adult stature with severe implications for females.

In this study, household income proved to be an independent predictor of VAD and stunting. Adolescents from households with low income of $\$ 120.96$ to 247.91 were more likely to be vitamin A deficient $(\mathrm{AOR}=0.23$; $95 \% \mathrm{CI}=0.058,0.929)$ and stunted $(\mathrm{AOR}=0.15 ; 95 \%$ $\mathrm{CI}=0.030,0.729)($ Table 5$)$. This finding collaborates with the report of Ene-Obong et al. ${ }^{28}$. The low income may have affected the purchasing power of the households with the result of food insecurity and consequently malnutrition. Low income in combination with high household size worsens nutrition status. Ayika et al. ${ }^{29}$ observed that the more the number of persons in a household, the lesser the amount of resources available to individuals in it and the lesser the number of persons in households, the more the equity distribution of food and other resources in the household. Food intakes especially those rich in iron and vitamin A depend on economic powers of the households. Households with low monthly income were less likely to afford iron and vitamin A rich foods especially during off seasons. This explains the reason for higher prevalence of stunting, and VAD among them than those with higher monthly income.

\section{Conclusion}

Based on our findings, iron deficiency anaemia and VAD among school children in Nsukka urban area were problems of severe public health importance. The prevalence of stunting and thinness among the school children was also high.

\section{Recommendation}

Emphasis should be laid on school health and feeding programmes, nutrition education, iron and vitamin A supplementation.

\section{Limitation of the study}

The study was limited to adolescent school children in Nsukka urban. This does not give a true representation of all adolescents in Nigeria but it has shown that urban adolescents are at risk of VAD, anaemia and stunting as their counterparts in the rural areas and should be included in all health and nutrition programmes aimed at reducing stunting and micronutrient deficiencies.

\section{References}

1. Ene - Obong HN. Eating right. Calabar: University of Calabar Press, 2001.

2. Brasel J. Changes in body composition during adolescence. In: Adolescent nutrition. Winick, M. (ed). New York John Wiley and sons, 1982 
3. Muller O, Krawinkel M. Malnutrition and health in developing countries. Canada Medical Association Journal 2005; 173 (3): 279-286.

4. Anyika JU, Uwaegbute AC, Olojede AO, Nwamarah JU. Nutrient Intakes of Adolescent Girls in Secondary Schools and Universities in Abia State of Nigeria. Pakistan Journal of Nutrition 2009; 8 (10): 1596-1602

5. Onimawo IA, Ukegbu PO, Asumugha VU, Anyika JU, Okudu H, Echendu CA et al. Assessment of anaemia and iron status of school age children (aged $7-12$ years) in rural communities of Abia State, Nigeria. African Journal of Food, Agriculture, Nutrition Development 2010; 10 (5): 2570 -2586 .

6. Ene-Obong HN, Odoh IF, Ikwuagwu OE. Plasma vitamin $\mathrm{A}$ and $\mathrm{C}$ status of in-school adolescents and associated factors in Enugu State, Nigeria. Journal of Health, Population and Nutrition 2003; 21 (1): 18-25.

7. Oninla SO, Owa JA, Onayede AA. Comparative study of nutritional status of urban and rural Nigerian school children. Journal of Tropical Paediatrics 2007; 53 (1): 39 -43. 8.Maziya - Dixon B, Akinyele IO, Oguntona EB, Nokoe S, Sanusi RA, Harris E. Nigeria Food Consumption and Nutrition Survey 2001 - 2003: Summary. Ibadan, International Institute of Tropical Agriculture (IITA), 2004

9. Aina TA, Etta FE, Zeitlin MF. Child development and nutrition in Nigeria: A textbook for education, health and social service performance. 1st ed. Lagos: Federal Government of Nigeria and UNICEF, 1992

10. UNICEF. Focus on Early and late adolescence 2011. Available at http://www.unicef.org/sowc2011/pdfs/ Early-and-late-adolescence.pdf. Accessed 10 August, 2015.

11. Dabone C, Delisle H, Receveur O. Poor nutritional status of school children in urban and peri-urban areas of Ouagadougou (Burkina Faso). Nutritional Journal, 2011; 10: 34. Available at http://www.nutritionj.com/ content/10/1/34. Accessed 26 September, 2013.

12. WHO. WHO growth standards for children 5 - 19 years. 2007; Available at http:/www.who.int/growthref/ en/ Accessed 26 August, 2011

13. WHO/UNICEF/UNU. Iron deficiency anaemia: Assessment, prevention and control: A guide for programme managers. Geneva, World Health Organization (WHO/NHD/01.3), 2001;

14. Neeld JB, Pearson, WN. Macro and micro method for the determination of serum vitamin A using trifluoroacetic acid. Journal of Nutrition 1963; 79: 454-62.
15. Federal Ministry of Health. National guidelines on micronutrient deficiencies control in Nigeria. T. Oguntona, SO Omojekun, FT Aminu, KO Demehin, AO Falana Eds. Abuja, Department of Community Development and Population Activities (Nutrition division), 2005

16. Assefa S, Mossie A, Hamza L. Prevalence and severity of anemia among school children in Jimma Town, Southwest Ethiopia. BMC Hematology 2014; 14:3 DOI:10.1186/2052-1839-14-3

17. Agarwal AK, Joshi HS Singh A. Vitamin A Deficiency among School Going Adolescents in Rural Areas of Bareilly. European Journal of Nutrition \& Food Safety 2014; 4(4): 318-324

18. Ngwu IM, Okeke EC, Ene-Obong HN, Ngwu EK. Consumption pattern of traditional foods by women and children in Igbo cultural communities of Ukehe and EdeOballa, Enugu State, Nigeria. Nigerian Journal of Nutritional Sciences 2009; 30(1): 94-102.

19. Zimmermann MB. Interactions between iron and vitamin A, riboflavin, copper and zinc in the aetiology anaemia. In K Kraemer, MB Zimmermann (Eds.), Nutritional anaemia. Switzerland, Sight and Life Press 2007 20. Solomons NW. Vitamin A and carotenoids. In B.A. Bowman \& R.M. Russel, (Ed.), Present knowledge in nutrition (8th Ed.). Washington DC, International Life Sciences Institute 2001

21. Goon DT, Toriola AL, Shaw BS, Amusa LO, Monyeki MA, Akinyemi O, Alabi OA. Anthropometrically determined nutritional status of urban primary schoolchildren in Makurdi, Nigeria. Bio Medical Central Public Health 2011; 11:769. Available at http://www.biomedcentral. com/1471-2458/11/769. Accessed 11 August, 2012

22. Wolde M, Berhan Y, Chala A. Determinants of underweight, stunting and wasting among schoolchildren. BMC Public Health 2015; 15: 8 PubMed DOI 10.1186/ s12889-014-1337-2.

23. Saaka M. Relationship between mothers' nutritional knowledge in childcare practices and the growth of children living in impoverished rural communities. Journal of Health, Population and Nutrition 2014; 32(2): 237-248

24. Okeke EC, Ene-Obong HN, Uzuegbunam A, Ozioko A, Umeh S, Chukwuone N. The Igbo traditional food system documentation in four States in Southern Nigeria. In Kuhnlein, HV, Erasmus B, and Spigelski, D (eds.) Indigenous People Food Systems: The Many Dimensions of Culture, Diversity and Environment for Nutrition and Health; FAO and Centre for Indigenous Peoples Nutri- 
tion and Environment (CINE), Rome. 2009; 251-281. developing countries. European Journal of Clinical Nutrition Available at http://www.fao.org/3/a-i0370e/i0370e13. 1994; 48: S45-S57 pdf. Accessed 12 December, 2015.

25. Yip R. Iron. In BA Bowman, RM Russell (Eds.), Present knowledge in nutrition. 8th ed. Washington DC, ILSI Press, 2001

26. Musa TH, Ali EA, Musa HH, Khan A. Anthropometric parameters of malnutrition in children 5-15 years old in Khartoum State. Sudan Journal of Public Health and Epidemiology 2013; 5 (8): 313-318.

27. Martorell R, Khan KL, Schroeder DG. Reversibility of stunting: Epidemiological findings in children from
28. Ene - Obong HN, Davidson GI, Mbah BO, Akah NN. Effect of mothers' socio-economic status and infant feeding practices on the nutritional status of children $(0$ -2 years) in a rural community in Enugu State, Nigeria. Nigerian Journal of Nutritional Sciences 2010; 31 (1): 42 - 46 29. Anyika, JU, Uwaegbute, AC, Onimawo, IA, Echendu, AC. Factors influencing food intake of adolescent female secondary and university students in Umuahia North and Ikwuano LGAs of Abia State. Nigerian Journal of Nutritional Sciences 2008; 29 (1): 125 - 134. 